J. Pijar MIPA, Vol. V No.2, September : 66 - 70

ISSN 1907-1744

\title{
ENERAPAN MODEL PEMBELAJARAN KOOPERATIF DENGAN PENDEKATAN SAVI (SOMATIC, AUDITORY, VISUAL, INTELLECTUAL) UNTUK MENINGKATKAN PRESTASI BELAJAR SISWA KELAS VIII SMP NEGERI 15 MATARAM TAHUN AJARAN 2008/2009
}

Gita Baitari $^{(1)}$, Ahmad Raksun ${ }^{(2)}$, dan Didik Santoso ${ }^{(3)}$

(1) Alumnus Program Studi S1 Pendidikan Biologi, PMIPA FKIP Universitas Mataram,

(2) dan (3) Dosen Program Studi Pendidikan Biologi, PMIPA FKIP Universitas Mataram

\begin{abstract}
Abstrak : Penelitian ini bertujuan untuk mengetahui pengaruh penerapan model pembelajaran kooperatif dengan pendekatan SAVI (Somatis, Auditori, Visual, Intelektual) dalam meningkatkan prestasi belajar biologi siswa kelas VIII SMP Negeri 15 Mataram tahun ajaran 2008/2009. Populasi dalam penelitian ini adalah semua siswa kelas VIII SMPN 15 Mataram dan sampel penelitian ádalah siswa kelas VIIIA dan VIIB .Jenis penelitian ini adalah quasi eksperimen dengan desain penelitian pre-test dan post-test group design. Dalam penelitian ini digunakan teknik cluster random sampling. Data hasil penelitian berupa hasil dari pre-test dan post-test dianalisis secara statistik menggunakan uji-t pada taraf signifikansi $95 \%$. Hasil penelitian menunjukkan bahwa nilai rata-rata pre-test dan post-test kelas eksperimen masing-masing sebesar 43,1 dan 85,6, nilai rata-rata pre-test dan post-test kelas kontrol masing-masing sebesar 46,625 dan 72,3. Hasil uji-t diperoleh t hitung 6,77 lebih besar dari t tabel 1,67 yang berarti terdapat perbedaan prestasi belajar biologi yang signifikan antara kelas eksperimen dan kelas kontrol. Kesimpulan hasil penelitian ini bahwa penerapan model pembelajaran kooperatif dengan pendekatan SAVI dapat meningkatkan prestasi belajar biologi siswa kelas VIII SMP Negeri 15 Mataram tahun ajaran 2008/2009.
\end{abstract}

Kata kunci : model pembelajaran kooperatif pendekatan SAVI, prestasi belajar.

\section{THE APLICATION OF COOPERATIVE TEACHING MODEL BY USING THE SAVI (SOMATIC, AUDITORY, VISUAL, INTECTUAL) APROACH TO INCREASE THE STUDENTS ACADEMIC ACHIEVEMENT IN BIOLOGY GRADE VIII OF SMPN 15 MATARAM ACADEMIC YEAR 2008/2009}

\begin{abstract}
This research is held to know the influence of cooperative learning by using the SAVI (Somatic, Auditory, Visual, Intellectual) approach in increasing the student's achievment at SMP Negeri 15 grade VIII with the academic year 2008/2009. The population of this research are the students of SMPN 15 Nataram grade VIII, while the sample are the students of VIII-A and VIII-B. The kind of this research is quasi experiment by using pre-test and posttest group design. Cluster random sampling is used in this research. The data is analyzed statisticly by using t-test in significant level $5 \%$. . The result of this reseacrh shows that, the average values of pre-test and post test for experiment group are 43,1 and 85,6 mean while average values of pre-test and post- test control group are 46,625 and 72,3. the result of t-test obtaned value of t-hitung 6,77 is more than t-tabel 1,67, it is mean that the different achievment of students in biology between the experiment group and control group significantly. The conclusion of this researc is the application cooperative learning model by using SAVI approach is able to increase the student achievment at SMP Negeri 15 grade VIII with the academic year 2008/200.
\end{abstract}

Key words : cooperative learning, SAVI approach, achievment

\section{PENDAHULUAN}

Hasil observasi awal penulis di kelas VIII SMPN 15 Mataram menunjukkan bahwa pembelajaran di sekolah tersebut masih belum dapat terlaksana dengan optimal, permasalahan yang sering dihadapi guru adalah rendahnya aktivitas siswa dalam pembelajaran IPA biologi. Dalam pembelajaran, guru lebih aktif dibandingkan siswa, siswa di dalam kelas hanya mendengar, mencatat, dan menghafal tanpa melakukan aktifitas yang mendukung terlaksananya pembelajaran dengan baik. Hal ini berkaitan dengan pendekatan yang digunakan oleh guru dalam pembelajaran yaitu pendekatan ekspositori. Pembelajaran yang menggunakan pendekatan tersebut dapat menyebabkan pembelajaran IPA Biologi menjadi kurang menarik dan kurangnya kemauan siswa untuk mengetahui, menemukan dan memecahkan masalahnya sendiri

Sehubungan dengan hal tersebut di atas, guru hendaknya dapat menciptakan pembelajaran yang melibatkan siswa secara aktif dalam proses belajar mengajar. Pengajaran IPA Biologi seharusnya meningkatkan keaktifan fisik siswa secara nyata dalam pelaksanaan pembelajaran. Aktif secara fisik yakni menggerakkan anggota badan dalam kegiatan pembelajaran, dengan bergerak dan berbuat siswa tidak akan merasa bosan, jenuh, dan membuat pembelajaran menjadi menyenangkan. Siswa dituntut untuk mampu mengungkapkan pendapat mengenai materi yang belum dipahaminya, sehingga siswa paham betul dengan materi yang dipelajarinya. Siswa juga akan merasa lebih paham jika mereka mengadakan pengamatan langsung di luar kelas untuk mendukung pembelajaran mereka. Selain itu siswa juga harus aktif secara intelektual yaitu aktif dalam memecahkan masalah pada situasi yang berbeda. Dalam hal ini dibutuhkan kemauan siswa untuk berfikir dan merenungkan bagaimana menyelesaikan suatu masalah berdasarkan pengalaman mereka selama proses pembelajaran. Guru mengarahkan dan mendorong siswa untuk berfikir dalam mencari dan menemukan suatu pemecahan masalah.

Salah satu pendekatan yang tepat dalam menunjang pembelajaran yang membuat siswa aktif secara fisik dan intelektual adalah pendekatan pembelajaran Somatis Auditori Visual dan Intelektual yang biasa disingkat SAVI. 
Pendekatan pembelajaran ini menekankan kepada siswa bahwa di dalam belajar tidak hanya duduk dan mencatat saja tetapi siswa harus melakukan sendiri (somatis), beragumentasi (auditori), mengamati secara langsung (visual) dan mencoba mencari solusi dalam pemecahan masalah (intelektual) [7]. Dalam mengembangkan alternatif pemecahan masalah tersebut dalam pembelajaran Biologi, maka peneliti melakukan penelitian tentang Penerapan Model Pembelajaran Kooperatif Pendekatan SAVI untuk meningkatkan Prestasi Belajar Siswa Kelas VIII SMP Negeri 15 Mataram Tahun Ajaran 2008/2009. Tujuan dilaksanakannya penelitian ini adalah untuk mengetahui adanya peningkatan prestasi belajar IPA Biologi siswa kelas VIII SMP Negeri 15 Mataram tahun ajaran 2008/2009 melalui penerapan pembelajaran kooperatif pendekatan SAVI.

\section{METODE PENELITIAN \\ 2.1. Jenis Penelitian}

Penelitian ini bersifat quasi exsperiment (eksperimen semu). Penelitian ini tidak mempunyai pembatasan yang ketat terhadap randomisasi [9]. Disebut penelitian semu karena eksperimen ini belum atau tidak memiliki rancangan eksperimen yang sebenarnya, yaitu sulit untuk mengontrol variabel-variabel luar yang mempengaruhi pelaksanaan eksperimen [10]

\subsection{Tempat dan Waktu Penelitian}

Penelitian ini dilaksanakan di SMP Negeri 15 Mataram. Pengambilan data penelitian mulai dari penentuan sampel sampai post-test dilaksanakan pada tanggal 20 Maret sampai tanggal 15 Mei 2009.

\subsection{Populasi dan Sampel Penelitian}

Populasi dalam penelitian ini ádalah semua siswa kelas VIII SMP Negeri 15 Mataram yang terdiri dari 9 kelas. Selanjutnya sampel yang digunakan dalam penelitian ini adalah dua kelas, yaitu kelas VIII-A dan VIII-B. Teknik yang digunakan dalam pengambilan sampel adalah Cluster Random Sampling. Pengambilan sampel dilakukan dengan mengacak 9 kelas yang menjadi populasi penelitian ini, sehingga terpilih 2 kelas untuk menjadi sampel penelitian yaitu kelas VIII-A dan VIII-B

\subsection{Prosedur Penelitian}

Penelitian ini dilakukan dalam dua tahapan yang terdiri dari tahap perencanaan dan tahap pelaksanaan tindakan. Kegiatan yang dilakukan pada tahap perencanaan adalah: (a) peneliti melakukan observasi lapangan yang dilanjutkan dengan observasi kelas, (b) menyusun tes hasil belajar dalam bentuk tes objektif, (c) membuat kisi-kisi instrumen yang akan diujikan, (d) membuat pedoman observasi untuk mengetahui aktivitas siswa dan guru selama proses belajar mengajar berlangsung, (e) menyusun RPP dengan menggunakan model pembelajaran kooperatif pendekatan SAVI dan model pembelajaran konvensional, (f) menyiapkan lembar kerja siswa (LKS), (g) melakukan uji validitas dan reliabilitas soal yang akan digunakan pada pre-test dan post-test, (h) membagi siswa dalam kelompok dengan jumlah anggota 4 - 5 orang.
Selanjutnya pada tahap pelaksanaan tindakan dilakukan: (a) memberikan pre-test pada masing-masing kelas yaitu VIII A dan VIII B untuk mengetahui kemampuan awal siswa sebelum diberikan perlakuan berupa model pembelajaran kooperatif pendekatan SAVI pada kelas VIII B, (b) melakukan pembelajaran kooperatif pendekatan SAVI pada kelas VIII B, (c) memberikan posttest pada kelas eksperimen dan kelas kontrol untuk mengetahui pengaruh perlakuan yang telah diberikan.

\subsection{Instrumen Penelitian}

\subsubsection{Test Hasil Belajar}

Instrumen yang digunakan dalam penelitian ini adalah tes dalam bentuk pilihan ganda yang dibuat oleh peneliti. Tes prestasi belajar yang digunakan terdiri dari 40 butir soal dengan setiap jawaban yang benar diberi skor 1 dan jawaban yang salah diberi skor 0. Sebelum digunakan, tes tersebut diuji cobakan terlebih dahulu agar diperoleh tes yang valid dan reliabel.

\subsubsection{Lembar Observasi Aktivitas Guru dan Siswa}

Lembar observasi digunakan untuk mengobservasi aktivitas siswa dan guru selama pembelajaran berlangsung. Observasi dalam penelitian ini merupakan observasi langsung, yaitu pengamatan dan pencatatan terhadap objek ditempat terjadinya atau berlangsungnya peristiwa, sehingga observer berada bersama objek yang diselidiki.

\subsection{Teknik Analisis Data}

\subsubsection{Uji F (Homogenitas Varians)}

Uji $F$ digunakan untuk mengetahui apakan varians bersifat homogen atau tidak [10]. Rumus yang digunakan adalah :

$$
\begin{aligned}
& \mathrm{F}=\frac{\text { varianterbesar }}{\text { varianterkecil }} \\
& \text { Varian }=\frac{\sum x^{2}-\left(\sum x\right)^{2} / N}{N-1}
\end{aligned}
$$

Homogenitas varian data sampel ditentukan dengan membandingkan harga $\mathrm{F}_{\text {hitung }}$ dengan $\mathrm{F}_{\text {tabel }}$ pada á $=5 \%$. Jika $\mathrm{F}_{\text {hitung }}>\mathrm{F}_{\text {tabel }}$ maka varians data bersifat heterogen. Jika $\mathrm{F}_{\text {hitung }}<\mathrm{F}_{\text {tabel }}$ maka varians data bersifat homogen.

\subsubsection{Data Prestasi Belajar Siswa}

Data prestasi belajar siswa pada kelas eksperimen dan kelas kontrol dianalisis dengan uji t pada á $=5 \%$ [3]

$$
\text { Rumus: } \mathrm{t}=\left[\frac{|M x-M y|}{N(N-1)}\right]
$$

Keterangan :

$\mathrm{M}=$ nilai rata-rata hasil perkelompok

$\mathrm{N}=$ banyaknya subyek

$\mathrm{X}=$ deviasi setiap nilai $\mathrm{X} 2$ dan $\mathrm{X} 1$

$\mathrm{Y}=$ deviasi setiap nilai $\mathrm{X} 2$ dan $\mathrm{X} 1$

\subsubsection{Data Observasi Guru dan Siswa}

Dalam penelitian ini kriteria penentuan skor pada saat observasi aktivitas guru adalah sebagai berikut [1] 
Tabel 1. Kriteria Penilaian Lembar Observasi Aktivitas Guru

\begin{tabular}{|c|l|l|}
\hline No & \multicolumn{1}{|c|}{ Deskriptor/Indikator } & KriteriaKriteria \\
\hline 1. & $\begin{array}{l}\text { Jika semua (3) } \\
\text { deskriptor yang nampak }\end{array}$ & Baik Sekali \\
\hline 2. & $\begin{array}{l}\text { Jika dua deskriptor yang } \\
\text { nampak }\end{array}$ & Baik \\
\hline 3. & $\begin{array}{l}\text { Jika ada satu deskriptor } \\
\text { yang nampak }\end{array}$ & Cukup \\
\hline 4. & $\begin{array}{l}\text { Jika tidak ada deskriptor } \\
\text { yang nampak }\end{array}$ & Kurang \\
\hline
\end{tabular}

Selanjutnya kriteria penentuan skor pada saat observasi aktivitas siswa adalah sebagai berikut [2].

Tabel 2. Kriteria Penilaian Aktivitas Siswa

\begin{tabular}{|c|l|}
\hline Skala Penilaian & \multicolumn{1}{|c|}{ Kriteria } \\
\hline $41-50$ & Amat Baik \\
\hline $32-40$ & Baik \\
$23-31$ & Sedang \\
$14-22$ & Kurang \\
$13-10$ & Sangat Kurang \\
\hline
\end{tabular}

\section{HASIL DAN PEMBAHASAN}

\subsection{Hasil Penelitian}

\subsubsection{Hasi Observasi Kegiatan Guru}

Hasil observasi aktivitas mengajar guru berdasarkan Rencana Pelaksanaan Pembelajaran (RPP) menunjukkan bahwa langkah-langkah yang harus dilaksanakan oleh guru dalam model pembelajaran kooperatif pemdekatan SAVI sebagian besar deskriptor dapat tercapai dengan baik.

Tabel 3. Hasil Observasi Aktivitas Guru dengan menggunakan model pembelajaran kooperatif pendekatan SAVI

\begin{tabular}{|l|l|l|}
\hline \multirow{2}{*}{ Indikator } & \multicolumn{2}{c|}{ Hasil Observasi } \\
\cline { 2 - 3 } & Pertemuan I & Pertemuan II \\
\hline $\begin{array}{l}\text { Kesiapan dalam } \\
\text { pembelajaran }\end{array}$ & Baik sekali & Baik sekali \\
\hline Memfasilitasi aspek somatis & Baik sekali & Baik sekali \\
\hline $\begin{array}{l}\text { Melaksanakan aspek auditori } \\
\text { dalam pembelajaran }\end{array}$ & Baik sekali & Baik sekali \\
\hline $\begin{array}{l}\text { Melaksanakan aspek visual } \\
\text { dalam kegiatan } \\
\text { pembelajaran }\end{array}$ & Baik sekali & Baik sekali \\
\hline $\begin{array}{l}\text { Melaksanakan aspek } \\
\text { intelektual dalam }\end{array}$ & Baik & Baik sekali \\
\hline $\begin{array}{l}\text { pembelajaran } \\
\text { Mengakhiri pembelajaran }\end{array}$ & Baik sekali & Baik sekali \\
\hline
\end{tabular}

\subsubsection{Hasil Observasi Kegiatan Siswa}

Hasil observasi menunjukkan bahwa kegiatan siswa pada kelas eksperimen, telah terlaksana dengan hasil 37 dan 38 dan setelah dikonsultasikan pada kategori skala penilaian pada lembar observasi didapatkan hasil dengan kategori baik.
Tabel 4. Hasil Observasi Aktivitas Siswa (menggunakan model pembelajaran kooperatif pendekatan SAVI)

\begin{tabular}{|c|l|c|c|c|c|}
\hline \multirow{2}{*}{ № } & \multicolumn{2}{|c|}{ Indikator } & \multicolumn{2}{c|}{ Perteman I } & \multicolumn{2}{c|}{ Pertemuan II } \\
\cline { 2 - 6 } & Skar & Ket & Skar & Ket \\
\hline 1. & $\begin{array}{l}\text { Kesiapan siswa dalam } \\
\text { menerima materi pembelajaran }\end{array}$ & 4 & Baik & 4 & Baik \\
\hline 2. & $\begin{array}{l}\text { Melakukan kegiatan somatis } \\
\text { sesuai dengan petunjuk } \\
\text { praktikum }\end{array}$ & 4 & Baik & 4 & Baik \\
\hline 3. & $\begin{array}{l}\text { Salingmenbantu antar anggota } \\
\text { kelompok dalamkegiatan } \\
\text { somatis }\end{array}$ & 3 & Sedang & 4 & Baik \\
\hline 4. & $\begin{array}{l}\text { Mengungkapkan pendapat } \\
\text { dalamdiskusi kelompok }\end{array}$ & 2 & Kurang & 2 & Kurang \\
\hline 5. & $\begin{array}{l}\text { Mengajukan pertanyaan } \\
\text { mengenai penjelasanguru yang } \\
\text { belumjelas }\end{array}$ & 4 & Baik & 5 & $\begin{array}{l}\text { Sangat } \\
\text { Baik }\end{array}$ \\
\hline 6. & $\begin{array}{l}\text { Melakukan pendataan atas } \\
\text { pengamatan gerakpada } \\
\text { tumbuhan dengantertib }\end{array}$ & 3 & Sedang & 3 & Sedang \\
\hline 7. & $\begin{array}{l}\text { Melakukan pengamatan dalam } \\
\text { suatueksperimen sesuai } \\
\text { prosedur }\end{array}$ & 4 & Baik & 5 & $\begin{array}{c}\text { Sangat } \\
\text { Baik }\end{array}$ \\
\hline 8. & $\begin{array}{l}\text { Mengerjakan soal latihan } \\
\text { dengan seksama }\end{array}$ & 4 & Baik & 5 & $\begin{array}{c}\text { Sangat } \\
\text { Baik }\end{array}$ \\
\hline 9. & Menjawab pertanyaanguru & 4 & Baik & 4 & Baik \\
\hline 10. & $\begin{array}{l}\text { Mampumembuat suatu } \\
\text { kesimpilansecara bersama- } \\
\text { sama }\end{array}$ & 5 & $\begin{array}{l}\text { Sangat } \\
\text { Baik }\end{array}$ & 4 & Baik \\
\hline & \multicolumn{1}{c}{ Jumlah Skar } & 37 & Baik & 38 & Baik \\
\hline
\end{tabular}

Data pada tabel 4 menunjukkan bahwa skor total yang diperoleh pada pertemuan I dan II yaitu 37 dan 38 . Data tersebut menunjukkan bahwa aktivitas peserta didik pada saat pembelajaran tergolong baik.

\subsubsection{Hasil Belajar}

Hasil belajar siswa kelompok kontrol dan eksperimen pada pokok pembahasan Gerak pada tumbuhan dapat dilihat pada tabel dan gambar di bawah ini :

Tabel 5. Hasil Belajar Siswa Pokok Bahasan Gerak pada Tumbuhan

\begin{tabular}{|c|c|c|l|l|l|l|l|}
\hline \multirow{3}{*}{ Kelompok } & \multicolumn{2}{|l|}{ Nilai Rata-rata } & \multicolumn{2}{l|}{$\begin{array}{l}\text { Nilai } \\
\text { Tertingi }\end{array}$} & \multicolumn{2}{l|}{$\begin{array}{l}\text { Nilai } \\
\text { Terendah }\end{array}$} & \multirow{2}{*}{ Beda } \\
\cline { 2 - 7 } & $\begin{array}{c}\text { Pre- } \\
\text { Test }\end{array}$ & $\begin{array}{c}\text { Post- } \\
\text { Test }\end{array}$ & $\begin{array}{l}\text { Pre- } \\
\text { Test }\end{array}$ & $\begin{array}{c}\text { Post- } \\
\text { Test }\end{array}$ & $\begin{array}{c}\text { Pre- } \\
\text { Test }\end{array}$ & $\begin{array}{c}\text { Post- } \\
\text { Test }\end{array}$ & \\
\hline Kontrol & 46,6 & 72,3 & 76 & 88 & 24 & 56 & 25,6 \\
\hline Eksperimen & 43,1 & 85,6 & 68 & 96 & 20 & 64 & 42,5 \\
\hline
\end{tabular}

Selanjutnya hasil uji t menunjukkkan bahwa besarnya $\mathrm{t}$ hitung $=6,77$ dan harga $\mathrm{t}$ tabel pada $\mathrm{a}=5 \%$ dan $\mathrm{db}=78$ adalah 1,67. Hasil uji t menunjukkan bahwa pembelajaran kooperatif pendekatan SAVI dapat meningkatkan prestasi belajar IPA biologi siswa kelas VIII SMPN 15 Mataram.

\subsection{PEMBAHASAN}

Dari hasil penelitian diperoleh bahwa model pembelajaran kooperatif dengan pendekatan SAVI (Somatis, Auditori, Visual, Intelektual) secara signifikan dapat meningkatkan prestasi belajar biologi siswa kelas VIII SMP Negeri 15 Mataram tahun ajaran 2008/2009. Hal ini disebabkan karena pendekatan ini meningkatkan 
keaktifan siswa secara nyata, yaitu siswa terlibat langsung dalam proses pembelajaran dan suasana belajar mengajar yang menyenangkan sehingga siswa lebih mudah menguasai konsep-konsep dan mampu meningkatkan pemahamannya terhadap materi yang dipelajari dan pelajaran yang diterima terasa bermakna karena menemukan sendiri jawaban-jawaban dari permasalahan yang ada, dan hal ini merupakan prinsip utama dalam proses pembelajaran. [8] menjelaskan bahwa dalam kegiatan belajar mengajar keterlibatan siawa secara total baik fisik maupun nonfisik sangat menentukan keberhasilan pembelajaran.

Selain itu pembelajaran biologi dengan menerapkan model pembelajaran kooperatif pendekatan SAVI menuntun siswa untuk belajar berdasarkan aktivitas. Hal ini sesuai dengan pendapat [7] bahwa pada pembelajaran SAVI, kegiatan belajar somatis, auditori, visual, dan intelektual memberi kesempatan kepada siswa untuk belajar berdasarkan aktivitas fisik dan intelektualnya.

Penerapan model pembelajaran kooperatif pendekatan SAVI menjadikan siswa lebih aktif dalam pembelajaran. Hal ini dapat dilihat pada kegiatan belajar somatis yang dilakukan siswa berupa kegiatan praktikum, kegiatan auditori berupa tanya jawab antara guru dan siswa dan diskusi kelompok, kegiatan belajar visual berupa pengamatan langsung dan melalui gambar, sedangkan kegiatan intelektual berupa kegiatan memecahkan permasalahan dan menjawab soal. Semua aktivitas belajar siswa tersebut menunjukkan bahwa siswa antusias dalam mengikuti kegiatan belajar mengajar karena adanya variasi dalam pendekatan yang digunakan oleh guru sebelumnya, sehingga mereka merasa senang dan tertarik untuk belajar biologi dan mereka menjadi lebih perhatian pada pelajaran yang diterima. Dengan meningkatnya keaktifan siswa di kelas, maka fungsi seorang guru bisa lebih efektif, tidak mutlak sebagai sumber pembelajaran dan pentransfer ilmu pengetahuan, tetapi lebih berperan sebagai teman belajar untuk membantu siswa memperoleh ide, keterampilan, sarana untuk mengekspresikan dirinya, dan cara-cara bagaimana belajar untuk menemukan jawaban dari permasalahan yang ada yang belum diketahui sebelumnya. Dengan demikian guru lebih aktif untuk mencari strategi pembelajaran dan mengorganisasikannya dengan sebaikbaiknya sehingga menciptakan proses belajar secara efektif. Dengan demikian hakekat mengajar adalah memfasilitasi siswa dalam belajar agar mereka mendapatkan kemudahan belajar [8].

Dari hasil observasi yang dilakukan diperoleh gambaran langsung tentang langkah-langkah guru atau kegiatan siswa yang telah terlaksana dalam penerapan model pembelajaran pendekatan SAVI sebagai salah satu pendekatan pembelajaran. Hasil observasi menunjukkan bahwa langkah-langkah guru maupun kegiatan siswa yang harus dilakukan dalam penggunaan pendekatan tersebut secara keseluruhan telah terlaksana dengan baik.

Dari penerapan pendekatan ini tercipta adanya saling ketergantungan yang bernilai positif dimana sesama siswa saling memberikan motivasi untuk meraih hasil belajar yang optimal melalui pembagian tugas. Adanya ketergantungan itulah yang selanjutnya memunculkan tanggung jawab individu terhadap tugas yang didapatkannya baik terhadap kelompok maupun interpersonalnya. [6] menjelaskan bahwa meskipun pengaruh pengajaran yang diterima oleh setiap siswa bersifat individual, namun proses pengajarannya itu sendiri dapat dilakukan dalam bentuk kelompok.

Mengajar secara efektif sangat tergantung pada pemilihan dan penerapan pendekatan mengajar yang serasi dengan tujuan mengajar. Cara belajar mengajar yang lebih baik ialah dengan melibatkan siswa secara aktif dalam kelas, merencanakan dan melaksanakan kegiatan tersebut secara kontinu melalui kerja kelompok. Kerja kelompok itu sendiri dapat dilakukan melalui pembelajaran kooperatif, dimana siswa belajar dalam kelompokkelompok kecil yang memiliki tingkat kemampuan yang berbeda. Dalam menyelesaikan tugas kelompok, setiap anggota saling bekerja sama dan membantu memahami suatu bahan pembelajaran. Dalam pembelajaran biologi itu sendiri perlu dikembangkan strategi pembelajaran yang dapat melibatkan siswa secara aktif dalam kegiatan pembelajaran untuk menemukan ide-ide mereka. Dengan demikian penerapan model pembelajaran kooperatif pendekatan SAVI dalam pembelajaran Biologi dapat meningkatkan prestasi belajar biologi.

Pembelajaran kooperatif berbeda dengan pembelajaran yang lain. Perbedaan tersebut dapat dilihat dari proses pembelajaran yang lebih menekankan kepada proses kerja sama kelompok. Dengan adanya interaksi antara anggota kelompok dapat mengembangkan hasil belajar siswa untuk berpikir mengolah berbagai informasi, dimana setiap siswa akan berusaha untuk memahami dan menimba informasi untuk menambah pengetahuan kognitifnya.

Pendekatan SAVI dirancang karena memiliki kelebihan utama, yakni kondisi lingkungan belajar kaya pilihan dan sesuai dengan semua gaya belajar serta memaksimalkan penggunaan indera saat belajar sehingga dapat meningkatkan prestasi belajar.

Peningkatan prestasi belajar melalui pembelajaran kooperatif pendekatan SAVI secara keseluruhan terjadi karena dalam belajar siswa melaksanakan serangkaian kegiatan belajar melalui kerjasama, baik dengan anggota kelompoknya, anggota kelompok lain maupun dengan guru. Selain itu, terlibatnya beberapa bentuk keterampilan yang dimiliki siswa pada saat pembelajaran berlangsung melalui kegiatan pengamatan meenyebabkan siswa memiliki sejumlah pengalaman belajar.

Hal yang dikemukakan di atas sesuai dengan pendapat [7] yang menyatakan bahwa belajar tidak hanya menggunakan otak tapi juga melibatkan seluruh tubuh dengan segala emosi, indera dan sarafnya. Sistem saraf manusia yang lebih merupakan prosessor citra membuat gambar konkret lebih mudah ditangkap dan disimpan daripada abstraksi verbal. Menerjemahkan abstraksi verbal menjadi gambar konkret, membuat abstraksi verbal lebih cepat dipelajari dan lebih mudah diingat. Selain itu, belajar adalah berkreasi, bukan mengkonsumsi materi pelajaran. Adanya kerjasama dapat membantu meningkatkan efektifitas kegiatan pembelajaran karena semua usaha belajar yang baik mempunyai landasan sosial, dan biasanya 
seseorang bisa belajar lebih banyak dengan berinteraksi dengan kawan-kawan daripada dengan cara yang lain.

Pada pembelajaran dengan pendekatan ini siswa dibiasakan untuk memecahkan masalah, menemukan penyelesaian masalah, menambah kepercayaan kemampuan berpikir sendiri, mengembangkan kemampuan mengungkapkan ide atau gagasan, membantu memberdayakan setiap siswa untuk lebih bertanggung jawab dalam belajar dengan demikian pembelajaran dengan pendekatan kooperatif salah satunya yaitu dengan model pembelajaran kooperatif pendekatan SAVI dapat digunakan sebagai salah satu alternatif pendekatan mengajar untuk meningkatkan prestasi belajar siswa, hal ini sesuai juga dengan hasil penelitian [5] yang menyimpulkan bahwa penggunaan model pembelajaran kooperatif dengan metode SAVI dapat meningkatkan hasil belajar siswa. Perbedaannya adalah penelitian ini menggunakan pendekatan penelitian tindakan kelas partisipasi.

Dengan demikian model pembelajaran kooperatif pendekatan SAVI merupakan salah satu pembelajaran alternatif yang dapat diterapkan untuk meningkatkan prestasi belajar IPA Biologi pada siswa.

\section{KESIMPULAN}

Penerapan pembelajaran kooperatif pendekatan SAVI dapat meningkatkan prestasi belajar IPA biologi siswa kelas VIII SMP Negeri 15 Mataram Tahun Pelajaran 2008/2009 secara signifikan.

\section{DAFTAR PUSTAKA}

[1] Anonim 2006. Instrumen Penilaian Kinerja Guru. Jakarta. Depdikbud.

[2] Anonim 2006. Model Penilaian Kelas. Jakarta. Badan Penelitian dan Pengembangan Kurikulum Departemen Pendidikan Nasional.

[3] Arikunto, S. 2007. Dasar-Dasar Evaluasi Pendidikan. Jakarta. Bumi Aksara.

[4] Arikunto, S. 2008. Prosedur Penelitian. Jakarta. Rineka Cipta.

[5] Lesmana, E. 2006. Penerapan Model Pembelajaran Dengan Menggunakan Pendekatan SAVI Dalam Pembelajaran Fisika Di SMPN 1 Kuripan Lombok Barat Pada Tahun Pelajaran 2005/2006. Skripsi Program Sarjana. Mataram. FKIP Universitas Mataram.

[6] Marwan, A. 2007. Belajar dan Pembelajaran. Jakarta. Rineka Cipta.

[7] Meier, D. 2002. The Accelerated Learning Handbook. Bandung. Kaifa.

[8] Mujiono, H. 2004. Belajar dan Pembelajaran. Jakarta. Gramedia

[9] Notoatmojo, S. 2005. Metodologi Penelitian. Jakarta. Rineka Cipta.

[10] Sugiyono. 2008. Penelitian Pendidikan Kualitatif $R$ dan $D$. Bandung. Alfabeta. 